\title{
2 Law and Biology: Menstruation, Amenorrhea, and Legal Recognition of Reproductive Status
}

Certain aspects of Islamic marital law had the potential to exacerbate or mitigate tensions surrounding fertility. As previously mentioned, this was true of Islamic legal tolerance for both polygamy and divorce. However, there were additional concepts which helped to shape the experience of infertility. The legal significance attached to menarche, menstruation, pregnancy, amenorrhea, and menopause also played a consequential role. So too did the legal dependence on, and distaste for, the mediating role played by midwives and other experts in female gynecology. In this chapter, we will examine medieval legal assumptions about what constitutes child-bearing age, the legal ramifications attached to a woman's menstrual cycles and their interruption, and how, counter-intuitively, social and legal flexibility regarding the length of gestation sometimes helped to protect and empower women who did not conceive at all.

\section{Menarche: the legal ramifications of the onset of menstruation}

The onset of menstruation was socially and legally significant in a number of ways that intersected with fertility and infertility. First, menarche triggered an expectation of fertility, i.e. the legal system operated under the assumption that, immediately following the onset of menarche, a woman was likely fertile and experiencing regular menstrual cycles. In post-menarchal adolescents, irregular menstruation was considered a defect, rather than normal. ${ }^{150}$ However, from a biomedical standpoint, it is common now, and likely was even more common in the past, for menarche to be followed by a year or several years of irregular menstrual cycles, many of which may be anovulatory. There is little textual evidence from any medieval population in the Islamic world that there existed an awareness of the modern scientific notion of adolescent subfecundity. (However, there is some evidence from the learned medical literature that women were considered to reach the age of peak fertility at a later point than menarche.) The ear-

150 The $18^{\text {th }}$-century scholar Ibn 'Ābidinn says, regarding the purchasing of a slave woman, that a girl who is between 15 and 17, and has not yet menstruated, is considered defective, since lack of menstruation is indicative of disease. He then says that if she menstruates, but only every 6 months, that too is a defect for which she can be returned to the seller. Ibn 'Ābidīn (d. 1252/1836), Ḥāshiyat Radd al-muhtārr (Riyadh: 'Ālam al-Kutub, 2003), 7:179.

Ә OpenAccess. (C) 2020 Sara Verskin, published by De Gruyter. (cc))BY-NC-ND This work is licensed under the Creative Commons Attribution-NonCommercial-NoDerivatives 4.0 License.

https://doi.org/10.1515/9783110596588-005 
lier women married, therefore, the more likely it would be that an extended period of time would elapse before they would get pregnant. Impatience with such an extended timeframe could potentially have negative, even disastrous, consequences, both medical and legal. A post-menarchal girl who was not pregnant might experience a desire or pressure to implement measures to cure her infertility, measures which themselves could damage her sexual organs.

The expectation of fertility meant that menarche also had the legal consequence of requiring post-menarchal divorcées and widows to experience three menstrual periods before remarrying, so as to establish that they were not pregnant with their former husbands' offspring. When women did not experience regular menstruation, it complicated their divorce and remarriage procedures, sometimes to the detriment of the women themselves and sometimes benefiting them.

Menarche was also consequential because it demarcated the end of legal minor-hood and the beginning of legal adulthood. ${ }^{151}$ Minor girls who were virgins could be legally married and consummate their marriages but, in those cases where they had been given in marriage by their guardian other than their father, once they reached menarche they potentially had a limited window of time to choose to unilaterally end their marriages. ${ }^{152}$ Unmarried minors who were not virgins (having been married and then either divorced or widowed all before reaching menarche) had to wait until legal majority to choose to remarry. This is significant for social historians because the women in this particular legal situation had reason to appear in court and thus to generate legal texts from which we can gather some information about the age and experiences of these adolescents.

\section{Hypothesizing average age at menarche and marriage and the fertility of young brides}

There was, and in some parts of the non-academic world still is, an incorrect presumption that North African and Asian girls mature and experience menarche at

151 Qarāmī, al-Ikhtilāf fì al-thaqāfa al-'arabìyah al-islāmìya, 328. Mahmoud Yazbak "Minor Marriages and Khiyār al-Bulūgh in Ottoman Palestine: A Note on Women's Strategies in a Patriarchal Society," Islamic Law and Society 9.3 (2002), 386-409.

152 If a girl was married off as a minor by anyone other than her father, then she could potentially exercise the choice to unilaterally end her marriage if she declared her desire to do so during the window of time between reaching menarche and engaging in post-menarchal sexual relations with her husband. 
earlier ages than European girls. ${ }^{153}$ There was also a presumption that, in premodern times, the onset of adolescence occurred even earlier than it does today. In an attempt to counteract such assumptions, Harald Motzki argued in 1985 that it was wrong to think that in the medieval Middle East (he specifically refers to $1^{\text {st }} / 7^{\text {th }}$-century Arabia, but also to later centuries and to a broader geographic region as well) females normally reached sexual maturity between age "nine to ten years," and instead he suggested that "the average was . . . for a girl, twelve to thirteen years, which corresponds approximately with modern European standards." 154 However, Motzki's suggested age range does not seem to be corroborated by either medieval texts or modern physical anthropology. In fact, late-antique, medieval, and Ottoman texts suggest that the average age of menarche was somewhat later than Motzki's suggested age of 12-13 years, with theoretical literature rarely if ever suggesting an average age of menarche younger than 14 years, and individual anecdotes referencing later ages. Moreover, studies of physical anthropology from other times and places suggest (though not definitively) a much later average age of menarche than what Motzki and other historians of the medieval Islamic world have assumed.

The medieval jurists understood menarche as being one of the ultimate signs of female legal physical maturity (bulūgh). The other indicators were: ihtilām (wet dreams), pubic hairs, pregnancy, and reaching a preset age threshold for the onset of adulthood. ${ }^{155}$ The minimum age for bulūgh in a girl was generally accepted to be nine years, and that was also legally considered to be the lowest

153 There is some evidence that the idea that "oriental" women living in hot climates reach puberty earlier than do European women is itself an "orientalist" fantasy in the Edward Saidian sense. Such claims were advanced by such noted $18^{\text {th }}$-century scientists as Boerhaave and Haller, and were refuted in the nineteenth and twentieth centuries. See K. Bojlén and M.W. Bentzon, "The Influence of Climate and Nutrition on Age at Menarche: A Historical Review and a Modern Hypothesis," Human Biology 40 (1968), 69. $20^{\text {th }}$-century scientific evidence about the role climate plays in menstruation suggests that either climate does not have much effect at all, or women in northern climes menstruate earlier, possibly due to vitamin-D deficiency, and those living closer to the equator tend to menstruate later. L. Zacharias and R. Wurtman, "Age at Menarche: Genetic and Environmental Influences," New England Journal of Medicine 280 (1969), $868-75$.

154 H. Motzki, "Geschlechtsreife und Legitimation zur Zeugung im frühen Islam" in Geschlechtsreife und Legitimation zur Zeugung ed. Ernst Wilhelm Müller (Freiburg/Munich: Karl Alber GmbH, 1985), 493. My translation.

155 For references to the application of maximum-age rulings, see L. Peirce, Morality Tales: Law and Gender in the Ottoman Court of Aintab (Berkeley: University of California Press, 2003), 151. 
possible age at which a girl can menstruate. ${ }^{156}$ As for the ages at which women would be considered adults in the absence of physical signs of maturity, 17 is the most commonly mentioned number, with individual jurists setting the age between 15 and 19 years. ${ }^{157}$ Such legal texts do not, however, imply that this number is meant to reflect an expected or average age of menarche. Several Roman and Byzantine physicians suggest that menarche and the onset of puberty begin at the age of 14, with some noting that "the best time for conception is about the eighteenth or the twentieth year."158 The Tunisian physicain Ibn al-Jazzār alQayrawānī (d. 369/980) also cites the age of 14, though he says menarche can occur as early as age 12. Both the physician Abū Bakr al-Rāzī (d. 311/923) and Ibn Sīnā mention that it dangerous for girls younger than 15 to experience childbirth due to their small size, but otherwise they do not mention an expected age of menarche.

We have some anecdotal information about menarche from Ottoman court cases in which women exercise their khiyār al-bulūgh (their choice to unilaterally annul their marriage immediately upon reaching menarche, if they had been married off as minors by guardians other than their fathers). In a study of court records dating from 1600 - 1623 in the Anatolian city of Kayseri, Ronald Jennings finds records in which women who had been married as infants confirm, now that they were no longer minors, that they accept the marriages arranged for them and are not exercising their right of annulment. Ages are often not mentioned, but where they are, the age is listed as "more than 15 years old." ${ }^{159}$ In his study of khiyār al-bulūgh in late-Ottoman Palestine, Mahmoud Yazbak cites the following information about ages. In 1871, a girl is married at 13 , and reaches menarche at the age of 14; in another a 14 year old who has not reached menarche is married off. In 1911 a girl who is "more than 14 years old" testifies that she has just reached

156 Ibn Qudāma (d. 620/1223), al-Mughnī (Cairo: Maktabat al-Qāhira, 1968) 7:461. Al-Hașkafī (d.1088/1677), Durr al-mukhtār in Hāshiyat Radd al-Muhtār 'alā al-Durr al-mukhtār (Cairo: Muṣțafa al-Ḥalabī, 1966) 3:507.

157 The $10^{\text {th }} / 16^{\text {th }}$-century Ottoman chef mufti Ebussuud Efendi considered children of both sexes to be of age as soon they demonstrated physical signs of maturity. "In the absence of such signs, females were considered to come of age at seventeen." L. Peirce, "Seniority, Sexuality, and Social Order: the Vocabulary of Gender in Early Modern Ottoman Society," in Women in the Ottoman Empire, ed. Madeline C. Zilfi (Leiden: Brill, 1997), 185. See also al-Mawsü'ah al-Fiqhìyah (Kuwait: Dawlat al-Kuwayt, Wizārat al-Awqāf wa-al-Shu'ūn al-Islāmīyah, 1987) 8:192 and Qarāmī, al-Ikhtilāf fì al-thaqāfa al-'arabìya al-islāmìya, 329.

158 Aetius of Amida, The Gynaecology and Obstetrics of the VIth century, tr. James Ricci (Philadelphia: Blakiston, 1950), 19.

159 R.C. Jennings, "Women in Early 17th Century Ottoman Judicial Records: The Sharia Court of Anatolian Kayseri," Journal of the Economic and Social History of the Orient 18 (1975), 78. 
menarche. In 1884, a girl who is 15 and still a minor comes to court having been promised as an infant to two different people who now seek to consummate the marriage. Yazbak does not mention any case of a girl claiming to have reached menarche prior to the age of 14 . It should also be noted, however, that the above-mentioned cases all come from several centuries after the medieval period and, for reasons that will be explored below, I argue that medieval living conditions would have likely meant that the average age of menarche would have been later than those mentioned in the Ottoman period in the same locales. In any case, to my knowledge, nowhere in the Middle East in any era of pre- $20^{\text {th }}$-century history do we find evidence to suggest women commonly reached menarche prior to the age of 14 .

Modern medical anthropology and European osteological historical records may give us more insight to the experience of women in the medieval Middle East. Studies of adolescence in living women from genetically similar but economically divergent populations have found that nutrition plays a significant role in determining the duration of adolescence and the onset of menarche. In developing countries, higher socio-economic status, higher caloric intake and, in particular, access to protein and fat from animal products, correlates with earlier menstruation, while underprivileged statuses, low caloric intake, and general malnourishment are associated with more prolonged puberty and later menstruation. ${ }^{160}$ Thus, in the late- $20^{\text {th }}$ century, there is only moderate variation between the mean age of menarche of middle-class girls in European urban centers and their middle-class counterparts in Middle East and North African cities. The mean age ranges between 12.2 years and 13.4 years. ${ }^{161}$ By contrast, the age of menarche ranges far more among those from varying economic backgrounds within the same region. For example, a 1982 study comparing wealthy urban adolescents in Kenya with their impoverished rural peers showed that, on average, rural girls experienced menarche more than two years later than wealthy girls. ${ }^{162}$ Urban well-nourished girls reached menarche at the median age of 13.2 years, while their rural counterparts did so at the age of 15.3 years. Similarly, in a 1998 study from India, well-off girls experienced menarche at a median age

160 The reason for this correlation is not entirely clear, and the data is not clear-cut. See R. Sprinkle, "The Missing Politics and Unsettled Science of the Trend toward Earlier Puberty," Politics and the Life Sciences 20.1 (March 2001), 43-66.

161 J. M. Tanner, Fetus Into Man: Physical Growth from Conception to Maturity (Cambridge: Harvard University Press, 1990), 146.

162 H. Kulin et al., "The Effect of Chronic Childhood Malnutrition on Pubertal Growth and Development," American Journal of Clinical Nutrition 36 (1982), 527-36. The article cites similar results from studies of adolescents in the United States and in India. 
of 12.1 years, while underprivileged ones did so at 15.4 years. ${ }^{163}$ In Western populations, where there are historical statistics available, the mean age of menarche has fallen dramatically even in the past century, by about three years. ${ }^{164} \mathrm{~A}$ similar decline of average age of menarche is currently being seen in populations in developing West African countries such as Gambia, Senegal, and Mali, where that age has declined from more than 16 years to less than 15 years in fewer than three decades. ${ }^{165}$

Turning to the medieval period, to my knowledge there are no studies of the physical maturity of adolescent human remains from anywhere in the medieval Middle East. However, in the past decade, there has been a great deal of osteological study of medieval and ancient European skeletons, especially in England and Italy, and there are also some studies comparing diets in medieval European and Middle Eastern populations. Studies of some individual European communities suggest that prior to the Black Death girls began puberty (i.e. breast development and growth spurts) at the same time as they did in the $20^{\text {th }}$ century, but menarche (which occurs after peak height velocity has been reached and the growth spurt has begun to decelerate) occurred later, and the maturation and growth process occurred over a much longer timeframe.

The ages at which individuals reached puberty, or achieved full adult maturity, were significantly different from those of modern people ... In adverse conditions, juvenile growth can continue up to the mid-20s . . . Measurement of the length of the femoral shaft in children from Barton suggests that they lacked the growth spurt that is indicative of puberty, from which we can infer that puberty was not experienced until the later teens ... The skeletal evidence suggests that young adults continued to grow into their early 20s, rather than reaching full physical maturity in their late teens. This has implications for our understanding of the lives of young medieval men and women. The age of menarche is assumed to have been around 15 years on the basis of medical texts from across medieval Europe ... however, the age of menarche is determined principally by nutrition. It is likely that the poor nutrition experienced by young women in medieval Yorkshire and Lincolnshire would have delayed the onset of menarche until their late teens. In modern societies menarche is usually followed by up to three years of adolescent infertility." ${ }^{166}$

163 A.S Parent et. al. "The timing of normal puberty and the age limits of sexual precocity: variations around the world, secular trends, and changes after migration.” Endocrine Reviews 245 (2003):673.

164 S. Scott and J. Duncan, Demography and Nutrition: Evidence from Historical and Contemporary Populations (Oxford: Wilson \& Sons, 2008), 95.

165 S. Prentice et al. "Evidence for a Downward Secular Trend in Age of Menarche in a Rural Gambian population,” Annals of Human Biology 37 (2010), 717.

166 R. Gilchrist, Medieval Life: Archaeology and the Life Course (Woodbridge: Boydell Press, 2012), 41-2. 
Adolescent infertility is caused by irregular menstrual cycles, of which many may be anovulatory. In modern populations, the later the onset of menarche for an individual female, the longer the post-menarchal length of time for her menstrual cycles to become regular. Thus a girl who begins menstruating relatively late in her teen years will likely experience a longer post-menarchal period in which she is less prone to becoming pregnant. It is not currently known how to evaluate whether this correlation between late menarche and longer subfecundity held true for medieval populations.

The most comprehensive attempt to chart adolescent development in a medieval population comes from a study of four urban cemeteries in England with corpses from the years 900 to 1550, one with "high status" occupants and the rest with "low status" occupants. With a total of 994 skeletons of people aged 10 - 25, Mary Lewis and Fiona Shapland analyzed the stages and ages of pubertal growth. Their sample indicated that there is a mismatch between what the medieval European legal and literary sources imply about the age menarche, and the osteological record. I would argue that the same is likely true in the Middle Eastern context.

Lewis and Shapland's analysis shows that adolescents began puberty at a similar age to modern children at around 10 -12 years, but the onset of menarche in girls was delayed by up to three years, occurring around 15 for most in the study sample and 17 years for females living in London. ${ }^{167}$ Modern European males usually complete their maturation by 16-18 years; medieval males took longer with the deceleration stage of the growth spurt extending as late as 21 years.

\begin{abstract}
This period of physical and sexual development is at odds with medieval canon law, where the legal age at which boys and girls could consent to marriage was 14 and 12 years, respectively. This encompasses a time when both would have experienced the onset of puberty, but predates the period in which the majority of females would have been fertile (c.15-16 years). In practice, it seems males and females in $13^{\text {th }}$ to $15^{\text {th }}$-century England married between 18 and 23 years . . . with urban females marrying slightly later . . ${ }^{168}$
\end{abstract}

While there are no direct studies of skeletons in the medieval Middle East to compare with these findings, there have been some studies of medieval Middle Eastern diets. It may be hypothesized, based on evidence from medieval Europe, that nutritional factors had a significant effect on the maturation process for

167 According to this study, $86 \%$ of females reached menarche when they were 15 years old. 168 M. Lewis et al, "On the Threshold of Adulthood: A New Approach for the Use of Maturation Indicators to Assess Puberty in Adolescents from Medieval England," Journal of Human Biology 28 (2016), $48-56$. 
Middle Easterners just as they did for Europeans. Evidence from Iraq, Syria, and Egypt in the middle ages, both before and after the Black Death, suggests that while there were significant differences in the specific diets of these populations, as compared to each other and as compared to the diets of those in Western and Southern Europe - certain nutritional elements were largely the same. Thus the content of bread differed quite substantially between the Middle East and Europe, but the high proportion of bread in the diet and in the budgets of most of the population did not. Prior to the Black Death, the price of meat, as well as other sources of fat and protein was so high as to be normally prohibitive for the working poor of Iraq, Syria and Egypt. ${ }^{169}$ (However, poultry was available.) In comparison to their European counterparts, the lower and middle classes of Egypt are thought to have consumed a similar amount of calories, but less meat.

The high cost of meat (mutton) in the Near East explains that the specialized workers (and probably also the small merchants) in the Near East had to allot one-fourth or even onethird of their income for it through all periods of the Middle Ages. In Southern and Western Europe the expenses for meat were relatively smaller. The nutritive value of the food which the working classes could afford was very small both in the Moslem East and in the Latin West. But since apparently until the Black Death, meat in Europe was much cheaper, the lower strata of the population had more proteins and lipids. ${ }^{170}$

There has been an interesting hypothesis based on skeletal evidence from England that children there had somewhat different diets from their parents, and that these diets consisted of even less meat. This would in fact be in keeping with Galenic humoral principles of the appropriate diet for the ages of man. ${ }^{171}$ While such Ga-

169 A. Sabra, Poverty and Charity in Medieval Islam: Mamluk Egypt, 1250-1517 (Cambridge: Cambridge University Press, 2000), 121-3 and E. Ashtor, "The Diet of Salaried Classes in The Medieval Near East," Journal of Asian History 4 (1970), 11. Ashtor estimates that in $11^{\text {th }}$-century (A.D.) Egypt, an adult male "worker" with a family could afford to buy approximately 1100 calories worth of food for himself, of which only 41 grams came from protein and 15 grams came from fats. By the $15^{\text {th }}$ century, this had increased greatly to 1900 calories, 82 grams of protein, and 45 grams of fat.

170 Ashtor, "The Diet of Salaried Classes," 20.

171 Gilchrist, Medieval Life, 52: "The nutritional risk to children may have been further exacerbated by medieval childcare practices. Isotopic analysis of skeletal remains from Wharram Percy showed a lower level of nitrogen for children aged between four to eight years, in comparison with older children and adults. This result was interpreted as indicating that children in this age group were fed a diet which was more plant-based, with a lower proportion of marine foods and meat or animal-based products . . . In other words, medieval childcare practices may have spe- 
lenic dietetic principles are mentioned in medical literature from the medieval Arab world, there is no evidence to either confirm or deny that such principles reflected or influenced common practice.

While it is not yet possible to draw definitive conclusions about the average age of menarche in any particular medieval Middle Eastern community, comparisons to modern populations and to medieval populations elsewhere in the world strongly suggest that in the Middle East, as in Europe, the average age of menarche was more likely to be 15 or 16 years or later, rather than the $12-13$ year age suggested by previous historians.

How did age at menarche relate to age at marriage? We have no statisticallyrich records available from any Middle Eastern community prior to the $19^{\text {th }}$ century. The earliest census known to me which attempts to account for all women in the population comes from Egypt, in a government study conducted between 1846-1848. In his analysis of that census, focusing on Cairo, Philippe Fargues noted that the ages of women at the time of marriage were recorded only in one district, that of Old Cairo. There "the average age of women upon their first marriage is 13.8 years, compared to 20.3 years for men." Among women between the ages of $10-14$, almost half (49.1\%) had already married. For women between the ages of $15-19,89 \%$ had ever been married. Kenneth Cuno, in his analysis of the census, noted that women younger than 15 were much less likely to be married in rural areas and, when they were, they tended to come from wealthier households. ${ }^{172}$

As for the pre-modern period, what anecdotal evidence we have suggests that it was not uncommon for women to marry at an early age. Yossef Rapoport attempted to make some statistical inferences about marriage patterns in Mamluk Cairo on the basis of the women mentioned in al-Sakhāwì's Daw' al-lāmi in which the $9^{\text {th }} / 15^{\text {th }}$-century writer chronicled the lives of 500 women. On the subject of the average age of first marriage for women, Rapoport wrote:

The majority of girls were married off in their early or mid-teens . . . Sitt al-'Arab married Abū Shāma when she was fourteen. Rābi'ah the daughter of the scholar Ibn Ḥajar al-'Asqalānī, first married at the age of fifteen, and his granddaughter married at the age of sixteen. Some married earlier. Al-Sakhāwī married an eleven-year old girl. Al-Maqrīzī’s mother

cifically denied children the foods rich in B12 which would have protected them from megaloblastic anaemia."

172 See P. Fargues, "The Stages of the Family Life Cycle in Cairo at the End of the Reign of Muhammad 'Alī, According to the 1848 Census," Harvard Middle Eastern and Islamic Review 5 (2000), 12 and 33. K. Cuno, Modernizing Marriage: Family, Ideology, and Law in Nineteenthand Early Twentieth-Century Egypt (Syracuse: Syracuse University Press, 2015), 66. The census is currently being digitized by Mohamed Saleh. 
first married when she was twelve. Orphan girls were usually married off while still minors, between ten and twelve. But it should be noted that some women were married at an older age. The historian al-Birzālī's daughter first married when she was nineteen. The virgin bride of Ibn Ḥajar was eighteen. ${ }^{173}$

Evidence from Jewish communities of Egypt indicates similar marriage patterns. ${ }^{174}$ Women could experience their first marriage as late as their late teens or as early as their pre-teens, with marriage in the early teens occurring frequently. It is a mistake to assume that those ages correspond with either menarche or the level of physical maturity one would expect from a woman of the same age in the modern Middle East. ${ }^{175}$ Based on the above considerations, it seems that first

173 Y. Rapoport, Marriage, Money, and Divorce in Medieval Islamic Society (Cambridge: Cambridge University Press, 2005), 38-9.

174 Child marriage within the Middle Eastern Jewish community is the subject of some scholarly debate between S. D. Goitein, M. Friedman, A. Grossman and R. Lamdan, with Lamdan and Grossman arguing that child marriage was so frequent as to be nearly the norm, and Goitein claiming that it was very rare. There appears to be little disagreement that $14-15$ years was a common age for marriage, and the debate centers on just how frequent marriages were to girls aged 10 to 12 or younger. The age range suggested by the Geniza sources and medieval Jewish responsa literature seems similar to the one represented in the Muslim Mamluk sources. R. Lamdan, "Child Marriage in Jewish Society in the Eastern Mediterranean during the Sixteenth Century," Mediterranean Historical Review 11(1996), 37-59. Cf. T. Meacham, "Marriage of Minor Girls in Jewish Law: A Legal and Historical Overview," in Jewish Legal Writings by Women, ed. by M. D. Halpern and Ch. Safrai (Jerusalem: Urim Publications, 1998), 27. Eve Krakowski has argued that because Jewish marriages consist of two stages, kiddushin and nisu'in, which in the Geniza period were often separated by a substantial period of time, and because the timing of nisu'in is often not specified within the Geniza documents, there are fewer recorded incidents of consummated minor marriage than previously thought. E. Krakowski, Coming of Age in Medieval Egypt (Princeton: Princeton University Press, 2018), 123.

175 On the subject of whether Islamic law permits marriage to minors, there seems to be some confusion in English-language non-scholarly publications which sometimes cite al-Nawawī (d. 676/1277) as saying that it is forbidden to consummate a marriage before menarche. This claim seems to be based on a 1914 English translation of al-Nawawìs Minhāj. The English text by E. C. Howard is as follows: "A father can dispose as he pleases of the hand of his daughter, without asking her consent, whatever her age may be, provided she is still a virgin. It is, however, always commendable to consult her as to her future husband; and her formal consent to the marriage is necessary if she has already lost her virginity. Where a father disposes of his daughter's hand during her minority, she cannot be delivered to her husband before she attains puberty." Minhaj et Talibin: A Manual of Muhammadan Law according to the School of Shafii, tr. E. C. Howard (London: W. Thacker \& Co., 1914), 284. A more literal translation of the Arabic text reads, "A father can marry off his virgin [daughter], whether a minor or an adult, without her consent; but it is commendable that he consult with her. He cannot marry off a non-virgin [daughter] except with her consent; so if she is a minor she is not married off until she reaches 
marriages for many medieval Muslim, Jewish, and Christian women in the medieval Middle East would have occurred at a time when the woman was unlikely to be either fertile or experiencing menstrual regularity, due to physical immaturity.

\section{Amenorrhea}

The literary evidence of the widespread practice of mid-teenage marriage. coupled with skeletal evidence that mid-teens were often not as physically developed as they are at the present day, has a number of ramifications for understanding fertility. The first is that it must have been common in women's first marriages for them to not experience regular menstruation at all, due to being pre-menarchal or to experiencing the irregular and anovulatory menses associated with post-menarchal adolescence. ${ }^{176}$ If and when a woman became fertile, it would also have been common for her not to experience regular menstruation due to pregnancy and lactation. This is, to some extent, borne out by evidence from fatwās, in which women who have born multiple children and are not old, testify that they have not experienced regular menstrual cycles in years, or indeed ever in the course of their marriage. ${ }^{177}$

Regular menstrual cycles are of supreme importance in Islamic divorce law, because they are used to determine the 'idda, the mandatory period which must elapse after a first marriage has dissolved before a second marriage can legally take place. The idda is significant in that a woman may not remarry until it is completed, ought not to leave the lodging provided to her by her former husband, and during that time her former husband has both financial obligations to her as well as sexual rights over her (if the divorce is not a triple, final one). The idda period for a divorced woman is determined to last either for

puberty.” As his commentators explain, he means that a non-virgin must give consent to be married, and she is legally capable of consent only once she has reached menarche, therefore the non-virgin minor cannot remarry until that point. Al-Nawawī, Minhāj al-țālibīn (Beirut: Dār alMinhāj, 2005), 375-6. On medieval legal attempts to define the minimum physical requirements for consummation, see Kecia Ali, Marriage and Slavery in Early Islam (Cambridge: Harvard University Press, 2010), 76 and Yazbak, "Minor Marriages and Khiyār al-Bulūgh in Ottoman Palestine: A Note on Women's Strategies in a Patriarchal Society."

176 See, for example, al-Fatāwa al-hindiyya (Būlāq: al-Mațba‘a al-Kubrā al-Amīriyya, 1892), 1:531: "A minor woman whose husband has divorced her, and three months minus one day has elapsed, and who then menstruates once, but does not menstruate three times - her 'idda has not been fulfilled."

177 See, for example, Ibn Taymiyya, Majmū‘ fatāwa (Medina: Majma‘ al-Malik Fahd li-Ṭibā‘at al-Muṣhaf al-Sharīf, 2004), 34:23. 
three menstrual cycles or three months, depending on her menstrual status. If she is pregnant at the time of the divorce, the 'idda lasts until she gives birth. If a woman is of reproductive age but has irregular or absent menstrual cycles, the 'idda may be prolonged far longer than the usual three months. It is not uncommon for legal discussions of 'idda to consider such prolonged periods, although to my knowledge such cases have not been studied systematically in the secondary literature.

Because the legal system was based on the assumption that women who reach menarche menstruate regularly and are thus potentially fertile, the circumstances of pregnancy and infertility looked identical to each other from the legal standpoint, since either may correlate with disrupted menstrual cycles! This meant that at the end of a marriage an infertile woman who failed to regularly menstruate could be tied to her ex-husband in much the same way as a woman who was pregnant at the time of her divorce. Her 'idda could be extremely protracted. This is oddly the mirror image of the medical situation in which the use of fertility drugs and abortifacients, i.e. tools of "menstrual regulation," also looked profoundly similar. (As will be shown in the next chapter, lack of menstrual bleeding could be taken as a medical indication that the woman was already in the early stages of pregnancy, i.e. experiencing a missed period. Or, lack of menstrual bleeding could be a medical indication that the woman was not experiencing normal, healthy reproductive cycles and thus could not conceive until menstruation was restored. Drugs that produced menstrual bleeding could thus either be construed as producing an abortion in a pregnant woman or as jump-starting a menstrual cycle in a barren woman. Some drugs and treatments which were supposed to result in the expulsion of blood from the uterus, in one context appear as abortifacients, and in another appear as fertility agents.)

Amenorrhea was thus associated with both fertility and infertility, and it seems to have thrown a wrench into the legal system bent on establishing paternity and sexual belonging. For amenorrhea legally indicated that a woman's body could have been impregnated by a relationship with a previous man, even as it indicated an inability to become newly pregnant. This problem is directly and repeatedly attested to in fatwā literature. Women who were not menstruating regularly could find it difficult to complete their 'idda and so could not permanently sever old marital ties and establish new ones. A "positive" flip-side to this problem also existed: in some legal schools a divorced woman who could claim amenorrhea (a claim which was difficult to legally dispute) could argue that she was, in fact, pregnant and thus argue that her ex-husband still owed her support or, if the ex-husband was deceased, inheritance. In this situation, presenting amenorrhea as indicative of pregnancy, rather than infertility, was 
a viable strategy for an infertile woman who wished to retain a legal and financial relationship with her former husband.

\section{‘idda and irregular menstruation}

Legal literature rarely makes explicit reference to women who are experiencing infertility. After all, infertility cannot be legally proven. However, there are many references to women who are experiencing amenorrhea and irregular menstruation. These references are found in the context of legal discussions of divorce and widowhood, since such conditions affected the length of the idda period. Given that the symptoms of amenorrhea and irregular menstrual periods in women of reproductive age correlate strongly with infertility and diminished fertility, it is worth delving into these discussions of the legal experiences of non-menstruating women in order to shed light on the legal landscape for infertile women. ${ }^{178}$

The length of the 'idda period for divorcées is usually counted as three menstrual cycles. ${ }^{179}$ However, for women who are post-menopausal (āyisāt), or who are minors who have not yet begun menstruating, the 'idda is calculated as three lunar months. ${ }^{180}$ From a legal perspective, a woman is considered to have reached menopause only once she has met two requirements: she has both ceased to menstruate and has reached a certain minimum age. The Fatāwā alhindiyya notes that even if a woman who has met those criteria and has therefore observed an 'idda based on months later appears to menstruate, then "the portion of her 'idda which has elapsed is canceled and she must recommence by calculating her "idda by menstrual cycles." ${ }^{181}$ The minimum age required to be considered past the age of menstruation is set between 50 and 62 years old

178 It is, of course, impossible to obtain statistics about the relative predominance of various causes of female infertility in different medieval contexts. However, research in MENA countries in the past 20 years suggests that tubal problems currently account for between $26 \%$ and $42 \%$ of female infertility, whereas pituitary, ovarian, and uterine disorders accounted for the remainder. Irregular menstruation is not usually a symptom of tubal blockages, but it is a symptom of the other kinds of disorders. In other words, if infertile medieval women in the Middle East suffered infertility from the same causes as do modern Middle Eastern women, between $58 \%$ and $74 \%$ of would have also potentially experienced irregular menstruation. See G. I. Serour et al., "Infertility: A Health Problem in the Muslim World” Population Sciences 10 (1991), 41-58.

179 By comparison, the waiting period in Jewish law is three months, not menstrual cycles, regardless of the circumstances. Mishna Yevamot 4:10.

180 If a minor is divorced, and during her three-month-long idda she menstruates for the first time, her 'idda begins anew, and is counted by menstrual cycles.

181 Shaykh Niẓām, al-Fatāwā al-hindiyya, 1:526-7. 
and varies both between and within legal schools. ${ }^{182}$ Among the Mālikīs the minimum age of menopause is set at either 50, or "one should ask women who are between the ages [of 50 and 70] about the blood which flows from women. If they say there is no menstruation at her age, she counts using months." 183 Most Shāfi'î authorities consider the minimum age of menopause to be 62 years, with al-Qalyūbī also citing opinions in favor of age 50 and age 60 . The minimum age of menopause is a matter of dispute among Hanafīs. Both 50 and 55 years are cited in the Durr al-mukhtār. ${ }^{184}$

Of course, in many medieval communities, precise birthdates went unrecorded for ordinary people, and thus there may not have been a practical opportunity to verify that a woman was, for example, 49 rather than 50 years old. Nevertheless, a woman who was said to be 49 and who had not menstruated recently would not, in theory, have been labeled menopausal by most scholars, with the exception of Ibn Taymiyya and his disciple Ibn Qayyim al-Jawziyya. ${ }^{185}$ That this could be a practical problem even for some relatively older women is suggested in a passage from the Masā’il of Ibn Hanbal transmitted by Ibn Hāni’ (d. 275/888).

I asked Abū 'Abdallāh [Ibn Ḥanbal] about a forty-year-old woman who married a man and remained with him for three years without menstruating or seeing any form of blood. Then the husband divorced her, and her 'idda from this first marriage was determined to be three months, upon which she married another husband. She remained with him for four years, more or less, and did not menstruate. How should her 'idda be determined, now that she has been divorced again? ${ }^{186}$

182 Similar ages are also found in medieval European literature. See D. W. Amundsen and C. J. Diers, “The Age of Menopause in Medieval Europe," Human Biology 45 (1973), 605-612.

183 Aḥmad ibn Muhammad al-Dardīr, al-Sharḥ al-saghīr in Bulghat al-sālik li-Aqrab al-masālik ilā madhhab al-Imām Mālik (Cairo: Mușțafa al-Bābī al-Ḥalabī, 1952) 1:497.

184 Al-Ḥașkafī, Durr al-mukhtār in Hāshiyat Radd al-muḥtār 'alā al-Durr al-mukhtār, 2:606

185 Their explanation hinges upon the root meaning of the $y \bar{a}$ 'isa, which is the word used for post-menopausal women but which literally means "hopeless" or "without expectations or prospects" in some particular regard. Ibn al-Qayyim explains. "Ibn Taymiyya said: Menopause is different for different women, and there is no cut-off point to apply to women. The intention of the verse is that each woman is without prospects with respect to herself. For menopause is the opposite of expectation, so when a woman becomes without prospect of menstruating, and she does not expect it, then she is menopausal, even if she is forty years old or thereabouts, though another woman will not be without prospect of menstruating even if she is fifty years old ...” Ibn Qayyim al-Jawziyya, Zād al-ma'ād, 5:583.

186 Ibn Ḥanbal, Masā’il al-Imām Ahmad bin Hanbal riwāyat Ishaq ibn Ibrāhīm ibn Hāni’ alNayṣābūrī (Beirut: al-Maktab al-Islāmī, 1979), 207. Parallel cases can be found in Ibn Taymiyya, Fatāwā, 34:19. Similar situations are mentioned briefly in the Fatāwā al-hindiyya, 1:528. 
In this instance, the divorcée is now in her forties, and has not menstruated in at least seven years. After her first divorce, three years prior, she waited three months before remarrying. If she could be legally considered post-menopausal, those three months would have been sufficient to finalize her first divorce, and she could go through the same procedure to finalize her second divorce. But Ibn Hanbal does not accord her that legal designation for either her first divorce or her second. Instead he cites several different opinions.

There is disagreement. There are those who say that her 'idda from the first [husband] should have been one year, such is the opinion of 'Umar.

But Ibrāhīm says, "If she has ever menstruated, even if only once, then the 'idda must be according to menstrual cycles and will last forever until she menstruates [again].

But Ibn Mas'ūd says: in the case of 'Alqama's wife, ${ }^{187}$ who fell ill and menstruated [only] twice and then died, 'Alqama inherited from her. The ruling of 'Umar b. al-Khaț̣āb was that if she does not know what has made her stop [menstruating], e.g. sickness or breastfeeding, she should wait 12 months, and then remarry.

Abū 'Abdallāh [Ibn Hanbal] said: My opinion is that they should be separated, that is, she and the husband who divorced her last, and then her 'idda from the first [husband] should be set at 12 months, and afterwards the 'idda from the second husband should be set at one year.

The first two opinions conflict with each other. In Ibrāhīm's view, in the absence of menstruation such a woman must wait twelve months between marriages. In Ibn Mas'ūd's view, in this situation she must wait three menstrual cycles regardless of how much time must elapse for that to occur. The third opinion, Ibn Hanbal's, suggests that Ibrāhīm's approach is correct under some circumstances, while Ibn Mas'ūd's approach is correct under others. A twelve-month waiting period is appropriate if menstrual cycles have stopped for no discernable reason, but if the amenorrhea can be attributed to a particular trigger, then the waiting period must be counted according to menstrual cycles regardless of how much time elapses. Ultimately, Ibn Hanbal concludes that the woman must now observe two years' worth of waiting, one year for each divorce.

Most later Hanbali jurists take the position that if a woman stops menstruating for reasons unknown, her 'idda is set at twelve months. This timeframe is usually explained as the combination of a nine-month-long waiting period to establish lack of pregnancy, at which point the lack of menstruation is attributed to menopause, followed by the three-month-long wait of a post-menopausal woman. However, under certain circumstances the delay in completing the idda could be longer than one year. This occurs when the onset of amenorrhea corre-

187 The story of 'Alqama ibn Qays is explained on p. 72. 
sponds to a known condition such as lactation or sickness, even possibly mental illness due to distress. Under such circumstances the woman must wait until her menses recommence or until she reaches the age of menopause, and only at that point may she begin calculating the three-month-long 'idda. ${ }^{188}$ On this point, early Hanbali scholars refer to a case where the circumstance causing the amenorrhea is "known" and, as a result, the 'idda is prolonged indefinitely, or until those circumstances change. The case is a story about "Alqama (d. 62/681), a companion of the Prophet. 'Alqama divorced his wife whereupon she became ill and stopped menstruating. Seventeen months later, she died. In that case Ibn Mas'ūd, another companion of the Prophet, ruled that 'Alqama inherited from her, thus indicating that she died while still within her 'idda period, proving that the 'idda can last for more than a year. ${ }^{189}$ There is a debate as to what motivated Ibn Mas'ūd's ruling. Ibn Hanbal's son ‘Abdallāh (d. 290/903) seems to understand the story to mean that since amenorrhea coincided with 'Alqama's wife having fallen ill, one could hope that menstruation would resume once the illness ended, and hence the 'idda could last as long as the triggering illness and for three menstrual cycles thereafter. ${ }^{190}$ Others interpreted the ruling in a different light, saying that the reason that the woman was still considered to be in her 'idda nearly a year and a half after her divorce was because Ibn Mas'ūd thought pregnancy could last for two years:

Ishā $q^{191}$ said . . . The meaning of the ruling about 'Alqama and his wife's illness is that Ibn Mas' $\bar{u} d$ favored the opinion that pregnancy could last two years, as 'Á'isha said: "A child does not remain in the womb more than two years." 192

Those who attributed to Ibn Mas'ūd the logic that, although gestation is usually nine months long, it is possible for it to last up to two years, and hence the idda can last that long, also argued that under all circumstances of amenorrhea, once the two years have passed and it is clear that there is no pregnancy, the divorcée can remarry immediately, without needing to undergo the three-month-long

188 Ibid., 7:465.

189 Al-Sarakhsī, a Hianafī, would later use the story to illustrate a point about the rights of a husband to revoke a divorce even during a prolonged 'idda. Al-Sarakhsī (490/1096), al-Mabsūt (Beirut: Dār al-Kutub al-'Ilmiyya, 1993) 6:19.

190 Susan Spectorsky, Chapters on Marriage and Divorce (Austin: University of Texas Press, 1993), 133.

191 Isḥāq b. Manșūr al-Kawsaj (d. 251/865).

192 Aḥmad ibn Muhammad al-Dardīr (d. 1201/1786), Sharḥ al-kabīr 'alā Mukhtasar Khaīl in Ḥāshiyat al-Dasūqī 'alā al-Sharh al-kabīr (Beirut: Dār al-Fikr, n.d.) 2:471. 
waiting period of the post-menopausal woman. ${ }^{193}$ The notion that gestation could last so long will be addressed later in this chapter.

Hanafīs and most Shāfi'īs take a very different position on the question of how a woman experiencing amenorrhea completes a divorce, a position which largely side-steps the question of whether the woman is possibly pregnant. Instead they maintain that a woman remains in her idda until such time as she had bled three times or reached the minimum age required to be legally considered post-menopausal. Once she reaches menopause, her idda is calculated as lasting three months, at the end of which she is free to marry. In theory, such laws would mean that an 'idda could last many years indeed. ${ }^{194}$ Interestingly, although the view that a non-menstruating woman must remain in her idda until old age is endorsed in the Durr al-mukhtār, the Hanafī author also suggests that it would be prudent in such a situation to direct a woman to a Mālikī judge, so that she may complete her 'idda in a single year. ${ }^{195}$ And in the Radd al-muhtār Ibn 'Ābidīn quotes al-Zāhidī (d. 658/1260) as saying that one fellow Hanafī jurist issued a fatwā based on the view of Mālik on this matter "because of need." 196

Mālikīs follow the nine-months-plus-three-months formula if menstruation seems to have ceased entirely. However, if menstruation occurs intermittently, the waiting period may be longer.

\footnotetext{
If the woman who is waiting for a year menstruates during that year, even if it is on the last day of that year, then she must wait again for a second menses, or until the end of [another] year. When the year ends without her menses appearing, her 'idda is over. But if her menses do appear within that year, even if it is on the last day, she must wait for a third menses, or a complete "white" year in which there is no blood, if she is free. If she is a slave, she stops at the second year. ${ }^{197}$
}

Such a situation, in which menstruation is highly infrequent, could theoretically delay a divorcée's remarriage for up to three years.

193 Ibn Qudāma, al-Mughnī, 7:463. Ibn Ḥanbal, Masāỉl al-Imām Ahmad ibn Ḥanbal wa-Ishạq ibn Rāhwayh (Medina:'Imādat al-Bahth al-'Ilmī, 2004), 4:1705-1707. A translation of the latter can be found in Spectorsky, Chapters on Marriage and Divorce, 189

194 al-Ūshī, Sirāj al-Dīn Abū Muḥammad 'Alī ibn 'Uthmān, Al-Fatāwā' al-Sirājīya (Lenasia, South Africa: Dār al-'ulūm Zakariyyā 2011), 232.

195 Ibid., 3:508; and al-Kāsānī (d. 587/1191), Baḍ̂a’’ al-ṣanāił, 2:195. The adoption of Mālikī practice in regard to this issue would be enshrined in the Ottoman "Law of Family Rights" in 1917. See N. J. Coulson, A History of Islamic Law (Edinburgh: Edinburgh University Press, 1964), 192.

196 Ibn ‘Ābidīn, Ḥāshiyat Radd al-muhtār, 5:186.

197 Aḥmad ibn Muhammad al-Dardīr (d. 1201/1786), Sharh al-kabīr 'alā Mukhtasar Khalīl in Ḥāshiyat al-Dasūqi 'alā al-Sharḥ al-kabìr (Beirut: Dār al-Fikr, n.d.) 2:471. 


\title{
The extended 'idda as a potential burden on women
}

Fatwās, particularly those of Ibn Taymiyya, shed some light on the negative consequences of long 'idda periods from the point of view of women seeking to end a marriage. (For the usefulness of the extended 'idda to women see the section below.) In one fatwa a, Ibn Taymiyya addresses the case of a young, married woman who seems to have stopped menstruating altogether, with no indication of when or if she will begin menstruating again. Her husband decides to divorce her. The petitioner asks: "Is the 'idda for her divorce measured by months or must she wait until she reaches the age of menopause?” Ibn Taymiyya responds by highlighting the plight of a woman stuck in this situation.

\begin{abstract}
If it is possible that her menses will return, and it is possible that they will not return, then she should wait one year and marry, as 'Umar b. al-Khațāb ruled regarding the woman whose menses had stopped without her knowing what had stopped them. She waits one year, and that is the common view, for example the view of Mālik and al-Shāfi'î. As for one who says that she must be of the age of menopause, that is a very weak view, with so much harm in it as to be unparalleled in the law. For it keeps her from marriage at the very time of her need of it and would only permit [marriage] to her once she no longer needs it [i.e. in her old age]. ${ }^{198}$
\end{abstract}

In another fatwa , Ibn Taymiyya reiterates the same logic and explicitly characterizes it as mașlaha (arrived at on the basis of the public interest). In this case, a woman's second husband has divorced her upon realizing that she had menstruated only once during her 'idda following her divorce from her first husband. In an effort to remarry her second husband, the wife then declares that she has reached menopause. As part of his answer, Ibn Taymiyya concludes with an attack on the Hanafī view.

According to [Abū Ḥanīfa] a woman in this precarious situation would remain in her 'idda until she grew old and reached the age of menopause, even though according to their opinion she would have to remain unmarried until 50 or 60 . But that would be such a hardship as to be an exception to the law, and so the mașlaha of the Muslims abolishes it. ${ }^{199}$

Ibn Taymiyya's fatwās also include a response to a case about a woman in her 'idda whose menses are "delayed" as a result of breastfeeding and who resorts

198 Ibn Taymiyya, Majmū‘ Fatāwā, 34:20.

199 Ibid., 34:17. 
to drugs in order to bring on menstruation. He notes that such menstruation does indeed qualify, so that the woman can be free to remarry. ${ }^{200}$

\section{A case study of irregular menstruation and the laws of 'idda}

If Ibn Taymiyya's fatwās seem relatively clear-cut, a fatwā attributed to the Mālikī Qāḍi 'Iyāḍ (d. 544/1149) demonstrates the complicated nature of calculating the 'idda and the significant resulting problems that an irregularly menstruating woman could have in entering and leaving a marriage. It also foregrounds the role of husbands and of other women in mediating an individual woman's encounter with the law. The case begins as follows:

When [Muhammad b. Aḥmad] married his wife Fāṭima bt. Muḥammad (known as Ibn Najjūma), he learned ${ }^{201}$ that she had a condition which delayed her blood. It concerned him that he might have contracted his marriage with her before the completion of her 'idda following her husband's, 'Alī b. Muhammad's, divorce from her. Muhammad therefore questioned and interrogated her, and informed her about what was required of her, whereupon she acknowledged to him that her blood had only come twice since her divorce from 'Alī, and that she was ignorant of [the requirements]. Muhammad withdrew from her and consulted with some trusted men of learning, who instructed him to divorce her, for she is not permitted to him. He therefore separated from her . . . ${ }^{202}$

The istiftā begins with Muhammad realizing that his wife is not menstruating as expected. This, he realizes, may have been the case prior to the marriage and he gets her to acknowledge that, in fact, she had menstruated only twice since her divorce after her previous marriage. He tells her "what was required of her." She says that she was ignorant of the requirement. He divorces her, apparently surprised by her confession.

The judge is then told that Muhammad, even before his marriage, was aware of the possibility that the requirements of 'idda were not being fulfilled. During his courtship, he had requested of a male intermediary, who in turn requested of his wife, that she educate the potential fiancée about the rules of 'idda.

200 Ibid., 34:19.

201 Lit. "it was revealed to him." This is the version that appears in al-Wansharīsī, al-Mi yār. The version that appears in Ibn Rushd's Fatāwā says "to her."

202 Ibn Rushd, Fatāwā Ibn Rushd (Beirut: Dār al-Gharb al-Islāmī, 1987), 2:1085-7 and Ahmad ibn Yahyā al-Wansharīsī, al-Mi' yār al-mu 'rib wa'l-jāmi' al-mughrib 'an fatāwā ahl Ifrīqiya wa'l-Andalus wa'l-Maghrib (Rabat: Wizārat al-Awqāf wa'l-Shu'ūn al-Islāmiyya lil-Mamlaka al-Maghribiyya, 1981) 3:401-3. 


\begin{abstract}
Muḥammad testified . . . that he had addressed Ḥājj Ḥaḍụur . . . to propose marriage between himself and Fāṭima b. Muhammad b. Najjūma, and Muhammad said to him: "Tell her to fear almighty God, her Lord, and to wait by herself until her 'idda is completed. Inform her that if she is of the sort who sees blood, then [she must do so] three times. If she does not see [blood], then [the 'idda] is three full months. She is not permitted to marry or to become engaged until after what I told you. Warn her against doing what she did with the Fāsī who proposed to her, when she decided to contract the marriage with him prior to the end of her "idda."

... Umm Qāsim, the wife of Ḥājj Ḥaḍụur, met with Fāṭima b. Muhammad Ibn Najjūma to inform her of all that Muḥammad b. Aḥmad mentioned above. [Umm Qāsim said that] she said all of this and informed her of it, and that Fāțima told her that her 'idda had been completed, and that she had seen blood three times since her divorce from her first husband.
\end{abstract}

This passage shows that that before his engagement Muhammad had warned Fātima (via intermediaries) to keep to herself and not to do what she did in the past, which was to become engaged to a man (the Fāsī, who may or may not have been her previous husband 'Alī) before she had completed her 'idda. It seems that Fāțima has a history of attempting to enter into marriages before she has completed her 'idda.

Throughout this history Fāțima is frequently informed by others about the laws of 'idda and yet she maintains that she was ignorant of what she is supposed to do.

... The husband seeks to take back the dower, but the woman is keeping it. She claims ignorance, but the husband has female witnesses saying that they informed her of what he said verbatim, and that the matter had been clarified to her during her 'idda from the first husband, which incidentally, according to one of them, was the second time [they had done so?]. The husband says that with this clarification, there is no possibility of her being ignorant ...

The husband seeks to annul his marriage and retrieve the dower he gave to his wife, on the grounds that by not menstruating three times since her previous marriage she had not completed her divorce and thus was not free to marry. He further claims that the woman must have lied in saying that she was free to marry, since multiple people had provided instruction to her about how the laws of 'idda work. The jurist disagrees, however, saying that she may well have thought she had fulfilled her 'idda obligations, and that if she is willing to issue a sworn oath that that was her state of mind, she may keep the dower like any other divorcee. 
The answer:

... It has not been confirmed what the Haajjjì’s wife said to/about ${ }^{203}$ her: i.e. whether - when [the Hājjij’s wife] informed her that the 'idda is three menses, and warned her against marrying before its completion - [Fātima] then said that her 'idda had been completed and that she has seen blood three times since her divorce from her first husband. My view is that since

[a] she denies that she was informed that the 'idda is three menses, and she was not informed of that, and

[b] she married only because she thought her 'idda from her first husband had been completed, and

[c] since she denies this within the limits of the law

she is not required to return any part of the dower to him. But if she refuses to swear [that this was the state of her marriage], she does not receive from him anything except the price of her vulva, ${ }^{204}$ and the rest returns to him ...

Everyone involved in the case assumes that Fātima must be confused about the rules of 'idda, at least initially. Her husband-to-be assumes that Fātima must be warned to keep to herself until she menstruates three times, and that she needed to be enlightened by Ḥājj Ḥaḍdūr. Umm Qāsim makes the same assumption. The other women affirm that they explained everything to her not once, but twice. Finally, the muftì seems to agree that there is room for ignorance here. There seems to be something truly complicated about the law of 'idda in this case such that it would make sense for the men and women involved to check and double-check the situation.

In David Powers's analysis of this case, he maintains that Fāțima's failure to comply with the laws of 'idda is motivated by selfishness, and that her claim of ignorance of those laws is obviously false. However, the most plausible way of accounting for the actions of all the people mentioned in the legal document is to take seriously the fact that Fātima's menstrual cycles were infrequent ("her blood was delayed"). This means that when Muhammad instructed her, by way of Hiâjj Ḥaḍụur and Umm Qāsim that "if she is of the sort who sees blood, then [she must do so] three times; if she does not see [blood], then [the 'idda] is three full months," Fātima's status really was potentially ambiguous. The complicated nature of the situation seems to stem in part of from the legal dichotomy differentiating between those who menstruate and those who

203 There are a number of textual variants among the manuscripts in this section. It might say "to her" or "about her."

204 On the use of this phrase see Kecia Ali, Marriage and Slavery in Early Islam, 151. 
do not. (The language of the instructions issued here is mostly Qur'ānic. It is possible, of course, that this language is used for official purposes in the legal document but does not reflect the actual wording used to instruct the woman.) Fātima believed she fell into the category of those who do not menstruate, and so she thought her 'idda ought to be calculated as three months long. The point of contention between the parties to the lawsuit is not whether Fātima knew that she was not allowed to marry during her 'idda. She was not ignorant of that. She says that "she only married someone thinking that her 'idda from her first husband had been completed" but, she claims, she never said that she had "seen blood three times" and did not know that she had to. The point of contention is whether Fātima knew that she still fell into the category of the menstruating woman, regardless of her lack of regular menstrual cycles. This, according to Fāțima and Qādī 'Iyāḍ, she could plausibly claim not to know. She did not know that a woman with oligomenorrhea such as herself had to see blood three times, rather than simply wait the three months. Muhammad and the other witnesses, for their part, testify that they explained the laws of idda many times and that she must thus have known that she was in the category of women who must calculate their idda by menstrual cycles.

Fātima's situation appears to have been further complicated by the semipublic and semi-private nature of menstruation, at least in this particular community. This attitude toward menstruation can be inferred from details from the fatwā. Prior to the marriage, it seems that Fātima was publicly known to have a menstrual problem - hence the women's repeated counseling of her regarding the laws of 'idda and Muhammad's warning that he knows about her and the Fāsī. ${ }^{205}$ So, in this community, there is a public dimension to menstruation. But there is also a private dimension to menstruation, hence the public's ignorance of the fact that Fātima had menstruated only twice since her most recent divorce. The public aspect of menstruation might have been somewhat obscured by the legal requirement that a woman remain at home during her 'idda period. Muhammad's message to Fātima at the time of the proposal includes the caution to keep to herself, indicating that this theoretical requirement was expected (by

205 One could make the argument that the public knew nothing about her menses at the time of the Fāsī relationship, and that they knew she had not completed her 'idda simply because not enough time had elapsed, e.g. she had been divorced only one or two months prior. However, if that were the case, then Muhammad's concerns would have been allayed with the passage of time. Given his concerned behavior at the time of his own engagement, one would have to argue that Muhammad and the women's concerns shifted from counting time to counting menses, and it just so happened Fāțima had a menstrual problem too. This strikes me as a plausible, if not the most likely, scenario. 
at least some) in this community to be put into practice. This would account for the fact that no one is sure how many times Fātima menstruated until she supplies the information herself.

So, at the time of her relationship with the Fāsī, Fātima was known to have a menstrual problem, but for some reason at the time of Muhammad's marriage both the female witnesses and Muhammad believed that the danger was past and, perhaps, so did Fātima. There are at least two scenarios in which this could happen. Perhaps at the time of her engagement to the Fāsī, Fātima had not experienced menstruation at all, or had only menstruated once and then stopped, and so the public image of Fātima was as someone experiencing amenorrhea. Once she menstruated again, it was mistakenly believed that she was now having regular cycles. Only once Muhammad and Fātima had been married for a while did it become clear that this was not the case.

Alternatively, at the time of her engagement to the Fāsī, Fātima had menstruated twice, and so the public image of Fātima was of a person who had regular, though long, cycles. By the time Muhammad proposed, he and the women thought that a sufficient interval had elapsed for her to have completed three cycles, and so they then did their due diligence and were satisfied when she affirmed that she had completed her 'idda. Meanwhile, Fātima believed that since she was no longer seeing blood she simply had to wait three more months. Only once she was married did it become clear to Muhammad that his wife did not have predictable menses. In either case the misunderstanding, deliberate or feigned, came to light only once the husband realized his wife menstruates only intermittently instead of having cycles and he chose to ask her how many times she had menstruated prior to her marriage.

In his article about this case, David Powers concludes that it showcases a woman craftily using faux-naiveté to manipulate the judicial system. ${ }^{206}$ However,

206 D. Powers, “Women and Divorce in the Islamic West: Three Cases,” Hawwa 1 (2003), 29- 45. Powers' analysis leaves out the vital piece of information that the wife has delayed menses. He argues, "Clearly knowledgeable about the rules of marriage and divorce, Fātima manipulated these rules, apparently for the purpose of lining her pockets with dīnārs and dirhams. She used her knowledge of the law to deceive not one but two husbands, in succession. Ironically, she defended her action with the claim - surely disingenuous - that she was ignorant of the law. The strategy appears to have worked." He also suggests that, in addition to being motivated by greed, "Fāțima may have had other motives, e. g., to extricate herself from a marriage that had been forced upon her by her marriage guardian, fear of pregnancy, or hatred of men." Powers' only evidence for his claim that Fățima is "clearly knowledgeable" is that she appears to avoid losing the lawsuit. There is no evidence that she wanted either divorce. If her purpose was to avoid marriage to this husband or to avoid pregnancy in general, it seems that by merely disclosing her menstrual state she could have avoided both. 
a more straightforward analysis of the fatwa - especially when read together with the laws of menopause and with Ibn Taymiyya's fatwās - suggests that the confusion, miscommunication, and frustrations experienced by Fāṭima and Muhammad make sense within the context of the application of the laws of 'idda for those with disrupted menstrual cycles. Moreover, since infertile women often experience such menstrual disruptions, infertile women would have been more likely than others to suffer from this frustrating legal situation, making it more difficult for them to conclude a divorce and to initiate a remarriage.

\section{The extended 'idda as a potential boon to women}

Medieval jurists, especially Mālikī ones (as well as $19^{\text {th }}$-century French colonial administrators and $20^{\text {th }}$-century anthropologists) also recognized that the extended 'idda could potentially be beneficial both to divorcées and to widows. This is so in situations when the former wife uses her extended idda to retain the rights due to her from her former husband. Two writings from the Andalusian jurist Ibn Rushd al-Jadd (d. 520/1126) illustrate this point. The first is a fatwa he writes in response to the case of a woman whose husband divorced her. As legally required, she lived in her former husband's house during her 'idda. After some time, when the "idda for one such as her ended," the former husband attempted to evict her from the house, at which point she declared that she was pregnant, and her former husband claimed that she was lying.

Ibn Rushd received a query from Badajoz about a woman whose husband divorced her, and she observed her 'idda in the house in which she had been divorced. The 'idda for one such as her ended and the husband, wanting to remove her from his house, told her that her 'idda had already ended. She declared that she was pregnant, in [the house], while her husband claimed she was lying and he wishes her to be examined by women. Must she swear that she suspects she is pregnant or not?

Answer: I have pondered the question and lingered over it. If she declared this after four months or so, she is to be believed without an oath. If she declared this after six months or so, she is believed so long as she swears. There is disagreement if she declared this near to the end of the year, and some say that she should be believed so long as she swears, while others say that she is not to be believed unless there was a hint of this previously. But if she declares this after the year has ended she is not to be believed unless the women examine her and corroborate what she declared. ${ }^{207}$

207 Ibn Rushd, Fatāwā, 3:1278-79, also in al-Wansharīsī, al-Mi'yār al-mu'rib, 4:482. 
Here, the divorced woman argues that she is still in her 'idda by virtue of suspecting that she is pregnant, and as a result she still has a right to lodgings paid for by her former husband. Her former husband denies that there is reason to believe that she is pregnant and wishes the matter to be settled by female experts, while the court considers whether she should be forced to swear an oath in order to be believed. Nowhere in either the question or the answer is it explicitly stated what indications the woman has that she is pregnant. Most likely it is the absence of menses but, particularly in North Africa, menstruation was still considered compatible with pregnancy. ${ }^{208}$

In his book of jurisprudence al-Bayān wa'l-tahṣill the same jurist, Ibn Rushd, addresses another set of (hypothetical) scenarios, in which a woman is divorced and her former husband dies some unspecified time later. She then seeks to inherit from him as a widow, on the grounds that she never menstruated after her divorce. ${ }^{209}$ The jurist is asked to consider the following situations, "in regards to a man who divorces his wife while she is [a] breastfeeding or [b] not breastfeeding, and then he dies. She claims that she has not menstruated and is seeking a share of the inheritance [i.e. the share normally due to a widow]." Since we are studying the potential legal options of infertile women we shall focus on his response to the situation in which the ex-wife/would-be widow claims to be experiencing amenorrhea unconnected with breastfeeding.

Ibn Rushd begins by citing the opinion of the Andalusian jurist al-'Utbī (d. 255/869). "He said, regarding a woman who is not breastfeeding: she is believed until one year has elapsed, whether or not she mentioned [her lack of menstruation] before, but she must swear to it - unless there is a rumor that she has already menstruated three times." Ibn Rushd explains that this means that if her divorce has occurred within the past year, and she is willing to swear that in that time she has not menstruated, then she is believed and hence inherits as a widow would.

He then addresses the situation if more than a year has elapsed since the divorce. If "she then seeks the inheritance, alleging that her 'idda has not ended due to there being a sensation present in her womb," then she is not believed until women examine her and corroborate her statement. Here Ibn Rushd explicitly connects the reason for the extended idda to the notion that the woman might yet be pregnant. Citing another authority, he says that if the examining

208 E. g. al-Wansharīsī, al-Mi'yār al-mu'rib, 4:524.

209 Ibn Rushd, al-Bayān wa'l-tahṣill (Beirut: Dār al-Gharb al-Islāmī, 1984) 5:419. 
women do find "suspected" pregnancy, ${ }^{210}$ she may remain in the lodgings provided for her 'idda for up to five years. If, after five years, she still claims to feel pregnant and to not be menstruating she is no longer believed. From the divorced woman's point of view, that means she can potentially obtain for herself up to five years of housing, if her lack of menstruation can be interpreted as pregnancy rather than infertility.

Ibn Rushd then mentions a debate as to whether her former husband had to be aware, prior to his death, that she was not menstruating (and thus that they were not fully divorced). He seems to subscribe to the opinion that the husband's knowledge is not requisite. However, he also mentions other opinions. He cites the opinion of Damascene Mālikī jurist Ibn al-Mawwāz (d. 281/894) who rules that she can only inherit if her former husband was aware during his lifetime that she had not menstruated yet. He further mentions an alternative construction of the relevant timeline: if her claim comes only four months into the divorce, she is believed without swearing to it. After six months she is believed only with an oath. And if she claims "not to have completed three menses due to delayed menstruation," but that claim emerges only after a year or two has elapsed, and her husband is already dead, she is not believed. He concludes that in a situation where the woman's claim or oath will not suffice, she should be examined by other women, who may provide expert testimony. ${ }^{211}$

The practical upshot of Ibn Rushd's discussion is that if a woman makes it known that she has not menstruated since her divorce, then she may claim the benefits due to a pregnant woman without any external corroboration, though she may need to swear an oath as to her status. It is not clear whether this oath is about only her lack of menstruation or also her "sensation" of pregnancy, or whether those are considered to be one and the same. If her claim to be experiencing amenorrhea or pregnancy is made late in the idda process, it is not rejected outright as impossible, but rather it is subjected to a higher standard of proof. The more expediently timed the woman's claims are, the higher the burden of proof required to substantiate them. That proof, however, need not be the eventual birth of a child, but rather testimony from expert women that the exwife exhibits some symptoms of pregnancy.

210 The language used here for suspicion of pregnancy is mustarāba and rība. This idiom is also used elsewhere in Ibn Rushd's writings in regard to a woman who claims to be pregnant while her ex-husband denies it. E. g. al-Wansharīsī, al-Mi'yār al-mu'rib, 4:482. The term also appears in the Mi'yār in at least one place where it is not attributed to Ibn Rushd. See al-Mi'yār almu'rib, 4:524 and 5:56.

211 Ibn Rushd, al-Bayān wa'l-taḥ̣ịl, 5:419-20. 
Particularly in North Africa, the testimony of midwives could have enough force to compel a man to financially support his ex-wife for years, if the testimony supported the claim that the ex-wife was experiencing a prolonged pregnancy. In Moroccan lore, a fetus could go into a state of hibernation in which the mother can feel its presence but it does not grow until it "wakes up" or is "awakened." This hibernating gestation can last for up to five years. Midwives were responsible for diagnosing this condition, known as the "sleeping fetus," rāqid, and their help was also sought in "awakening" the rāqid and so that normal pregnancy could "resume." The rāqid is well known within secular scholarship of Islamic law as an instrument for protecting the reputation of women who birth children at inconvenient moments, moments that would indicate that they conceived when they were unmarried or their husbands were not present to impregnate them. However, the notion of rāqid protected not only women with awkwardly-timed pregnancies, but also women who did not appear to be pregnant at all. Multiple medieval fatwās which reference extended gestations do not refer to situations in which the paternity and circumstances of the conception of a baby are suspect, but rather to a situation in which a woman claims to be pregnant despite not yet producing a baby. ${ }^{212}$ Until recently, ${ }^{213}$ the rāqid was understood by Europeans working in Morocco as primarily a coping mechanism for infertile women. ${ }^{214}$ In reference to late $19^{\text {th }}$ and early $20^{\text {th }}$-century Morocco, Ellen Amster writes:

The raqid prevented unilateral divorce (talāq), because according to the Qur'an, a man cannot divorce a pregnant wife before she gives birth, after which he owes her two years of maintenance for breast-feeding. A divorced woman could thus receive up to five years of maintenance by claiming a raqid pregnancy, and a widow could delay the division of her husband's succession by declaring herself pregnant at his funeral; any child born within the five-year delay period would consequently inherit. Shari'a and Berber customary courts left the diagnosis of the raqid to the woman herself, her mother, or a midwife . . . In the Morocco of the twentieth century, French physicians were incredulous that shari'a judges could believe such a "physiological absurdity." Doctors saw the raqid as a woman's

212 E. g. al-Wansharīsī, al-Mi'yār al-mu'rib, 3:224-25.

213 By the late-twentieth century, it had re-emerged as a way of coping with the pregnancies of North African women whose husbands were living in Europe as migrant workers.

214 F. Legey, The Folklore of Morocco, tr. Lucy Holtz. (London: Unwin, 1935), 105-106: “A barren woman will never admit her sterility. She believes that she has conceived, and that her pregnancy is delayed by a spell ... she imagines that she was pregnant, and the child fell asleep ... she then abandons herself to certain practices in order to wake it up ... It is also thought that if this magic medicine does not wake up the child, it will facilitate its expulsion, and that the woman will then conceive normally." 
ruse to avoid divorce, and Dr. Delanoe commented wryly, "Every sterile woman claims to have [sleeping child.]"215

Amster goes on to show that French doctors and the French legal system were seen as instrumental in upholding the prerogatives of living ex-husbands and the kin of deceased ex-husbands, who denied that their ex-wives and ex-inlaws were pregnant. By contrast, the courts based upon shari ${ }^{\top} a$ and customary law were perceived as being more protective of the rights of such women, and especially their right to lodging during the idda. Similarly, Noel Coulson has noted that in modern Egypt too, efforts to reform the legal code along more European lines included provisions to protect ex-husbands from the demands of an extended 'idda on the basis of long gestations. ${ }^{216}$

It should be noted that while the concept of the sleeping fetus is most commonly associated with Morocco, the notion that a fetus could gestate beyond one year is found in sources from Medina and is acknowledged by not only the Māliki school, but also by the other three Sunnī schools, with the Hanafīs having the most narrowly defined limits of possible gestation, setting it at two years and other schools mentioning four, five, and seven year limits. ${ }^{217}$ Sometimes even longer gestations are mentioned. In a remarkable account of his family life, a learned Cairene named Burhān al-Dīn Ibrāhīm al-Biqā‘ì (d. 885/1480) describes the nine-year-long pregnancy of his concubine, Hasbiya Allāh, with his muchanticipated child. He mentions that a rival wife and some acquaintances scoff at the concubine's claim, but al-Biqā'ī asserts that his experience has the support of both medical authors and female midwives who have periodically examined the "pregnant" woman. ${ }^{218}$

215 E. Amster, Medicine and the Saints (Austin: University of Texas Press, 2013), 167-8.

216 Coulson, A History of Islamic Law, 176.

217 See al-Sarakhsī, al-Mabsūț. 4:45. Ibn Rushd the grandson (Averroes) takes exception to the notion of long gestations. He writes, "They disagreed about the longest period of pregnancy through which the father can be associated with the child. Mālik said that it is five years, while some of his disciples said it is seven. Al-Shāfi'ī said that it is four years. The Kūfīs said it is two years. Muhammad ibn al-Hakam said it is a year. Dāwūd said it is six months. This counting is based on practice and experience. The opinions of Ibn 'Abd al-Hakam and the Z̄āhirites are closer to the normal. The rule should be based upon what is normal, not upon what is rare, which would, perhaps, be impossible.” Translation from Imran Ahsan Khan Nyazee, The Distinguished Jurist's Primer: A Translation of Bidāyat al-Mujtahid (Reading: Garnet, 2000), 2:433.

218 al-Biqā'ī, Izhār al-'aṣr li-asrār ahl al-'așr (Riyadh: n.p., 1993) 3:43-4. Here both the "mother” and the "father" appear to be motivated in part by animus toward one of his wives and her child. See. L. Guo, “Tales of a Medieval Cairene Harem: Domestic Life in al- Biqā‘ī’s Autobiographical 


\section{Women's testimony, privacy, and expertise}

One striking aspect of references to women's reproductive statuses is the extent to which they could remain private, unknown to anyone but the woman herself, at least in some communities. This is somewhat surprising given the close quarters in which people lived, the significance of menarche for women's legal and ritual identities, and the importance of purification after menstruation for all kinds of ritual activities. Despite the public significance of menstruation, all of the above-mentioned legal cases and hypothetical questions indicate that, in many places, it was possible for no one but the woman herself to be aware whether she was currently experiencing regular menstrual cycles. ${ }^{219}$ Thus the biological fact of menarche and menstruation or lack thereof was, in some places, a private matter, such that an individual woman might exercise some control over the timing of its becoming a social fact.

For example, al-Mi'yār al-mu'rib, the famous collection of North African and Andalusian fatwās compiled by al-Wansharīsī (d. 914/1508), includes many cases where no one but a girl herself is aware whether she has reached menarche. ${ }^{220}$ It also includes several cases in which a husband is surprised to find that his new wife is physically immature, and this is particularly true in the case of fatherless brides. ${ }^{221}$ Sometimes this in and of itself causes a legal problem, ${ }^{222}$ but in other cases we hear of it only because it is invoked as part of a legal counterclaim,

Chronicle," Mamluk Studies Review 9 (2005), 111. Interestingly, in addition to experiencing food cravings, Ḥasbiya Allāh's main form of signaling her pregnant status is by attempting and failing to complete the Ramaḍān fast. Al-Biqāīi notes her attempts to fast and her becoming overcome by dizziness by noon, despite her self-care. Al-Biqāâi further mentions that after failing to fast during Ramaḍān for two years in a row, the woman made up the fasts over the course of another two months, as religiously required, and both he and she engaged in other forms of expiation for her failure to fast. It may be worth investigating whether prematurely breaking the fast was considered to be a quintessential form of intentionally or inadvertently revealing a pregnancy, in the way that avoiding alcohol in social situations or vomiting unexpectedly is in American culture. 219 Cf. M. H. Katz, "Scholarly Authority and Women's Authority in the Islamic Law of Menstrual Purity," in F. Kashani-Sabet and B. Wenger, ed., Gender in Judaism and Islam: Common Lives, Uncommon Heritage (New York: New York University Press, 2014), 85-87; 93.

220 E.g., al-Wansharīīi, al-Mi'yār al-mu'rib, 3:245; 3:266.

221 For a summary of the legal ramifications of marrying off fatherless brides see Yazbak "Minor Marriages and Khiyār al-Bulūgh in Ottoman Palestine," 392-3. For an analysis of juristic opinions pertaining to minor marriage more generally see Nūr al-Dīn 'Abd Allāh ibn Ḥumayyid al-Sālimī, Ị̇̂ạh al-bayān fī nikāḥ al-ṣibyān: aḥkām tazwīj al-ṣighār (Beirut: al-Dār al-'Arabiyya lil'Ulūm, 2006).

222 E.g. Ibn Rushd, Fatāwā, 294. al-Marwarrūdhī, Fatāwā, 323, 335. al-Nawawī, Rawḍat alțālibìn, 246. 
rather than because it is at the heart of a legal dispute. For example, a fatherless girl with a seemingly unscrupulous uncle is married off "when she was not even close to maturity" and dies in that state. ${ }^{223}$ Her relatives sue for her estate on the grounds of her minority, and her husband sues on the grounds that he thought she was mature. Sometimes the bride herself seems to be pretending to be more physically mature than she is, and at other times the husband disputes with the bride's family and claims that she is in fact mature enough to endure sexual relations, while they claim that she is not. ${ }^{224}$ We even have a case in which both occur: a fatherless girl being raised by her kin is married off and then, at the point of consummation, she tells her husband that she has not reached puberty (bulūgh), and he divorces her on the spot. He later regrets his decision because she is in dire need, but he is told she cannot remarry until she can prove puberty. Then the girl announces that she has reached puberty and officially proves to some unspecified powers-that-be that she shows breast-budding, which is a sign of maturity. The couple then remarry but at around the time of consummation she begins to "hate" her husband, and then tells him that she has not, in fact, reached puberty and flees. He denies her claim of immaturity. Both sides then each bring an expert woman (bayyina), who offer competing expert opinions about whether the girl shows signs of breast-budding. ${ }^{225}$ All this suggests that these physical characteristics were often not a matter of public knowledge until such time as a legal dispute arose and progressed to the point where expert witnesses were required, and that even at this point physical characteristics were subject to interpretation and manipulation.

It should be noted here that numerous fatwās in al-Wansharīsī's al-Mi'yār almu'rib indicate that while a father could marry off a virgin daughter who had not yet reached menarche, the jurists and Maghribi/Andalusi society in general were scrupulous about waiting to marry off a fatherless girl until she either reached menarche or displayed some other sign of pubescence. (Some Mālikī sources specifically list not menarche, but rather being physically tall enough to birth a child, as the minimum developmental requirement for a virgin orphan girl to marry. ${ }^{226}$ ) Fatwās further demonstrate that at times these measures protected girls from exploitation and sexual trauma and, as we have seen, at other times orphan girls deliberately tried to circumvent these measures and pretend to be older in order to marry and thereby save themselves from deprivation.

223 al-Wansharīsī, al-Mi'yār al-mu'rib, 3:96-7.

224 Ibid., 3:8-9.

225 Ibid., 3:48-9.

226 Ibn Abī Zayd al-Qayrawānī, Kitāb al-nawādir wa’l-ziyādāt (Beirut: Dār al-Gharb al-Islāmī, 1999), 4:398. 
A variation on this theme of strategic manipulation of menarchal status is alluded to in a $9^{\text {th }} / 15^{\text {th }}$-century slave-buying guide by an Egyptian Hanafĩ jurist. Obviously, the book is written with the interests of a male slaveowner in mind, and thus it may not be possible to take at face value its account of slave women's motivations. Nonetheless it is worth noting the book's claim that a female slave might engage in strategic misrepresentation of her menstrual status for legal purposes. "If a slave girl declares that she is not mature, do not trust her statement in this regard, whether it is [a claim to be] younger or older. For a slave girl might have entered puberty while subject to a [previous male owner] but has concealed it due to her desire for a child, so that she might be freed from the bondage of slavery. Many slave girls pretend to be infertile to deceive their owners. Therefore, whoever wishes to sell a slave girl should display her for sale only while she is menstruating." 227 The implication here seems to be that a slave woman might secretly hope to conceive, because a slave who is impregnated by her owner is entitled to certain privileges. According to most jurists such a woman, known as an umm al-walad (mother of a child), can never be sold away from her young child. The child is the property of her owner/the child's father and, if the enslaved mother is sold to a different owner, the sale is nullified according to most legal authorities. Moreover, there developed early on in Sunnī legal history a consensus that, upon the death of the owner, both mother and child would go free and the child would inherit from the father. For this reason, the author of the slave-manual suggests that a slave woman might resort to trickery to become an umm al-walad. The woman might pretend she is too young to get pregnant so as to "entrap" her new owner into impregnating her and to thereby improve her legal status. The slaveowner would have sexual relations with her thinking that he does not risk begetting a child because his slave is either too immature or is otherwise infertile. Or she could trick someone in the slave market, by being already pregnant but concealing her pregnancy at the point of being re-sold, knowing that once she is sold and reveals she has been impregnated by her former owner, she is no longer legally subject to the new owner. ${ }^{228}$ Other slave-buy-

227 Maḥmūd b. Aḥmad al-'Ayntābī, al-Qawl al-sadīd fī ikhtiyār al-imā’’ wa'l-ābīd (Beirut: Mu'assasat al-Risāla, 1996), 38.

228 The laws governing the position and rights of the umm al-walad, the slave who had birthed her master's child, were subject to a great deal of dispute, particularly in the earlier periods of Islamic legal development. See Mirza, "Remembering the Umm al-Walad.” See also G. Lydon, and B. Hall, "Excavating Arabic Sources for the History of Slavery in Western Africa," in African Voices on Slavery and the Slave Trade, ed. A. Bellagamba et. al., (Cambridge: Cambridge University Press, 2016), 24. See also, S. Marmon, "Domestic Slavery in the Mamluk Empire: a Prelimi- 
ing manuals, one from $5^{\text {th }} / 11^{\text {th }}$-century Iraq and another from $6^{\text {th }} / 12^{\text {th }}$-century Spain also mention misrepresentations of menstrual status, but emphasize the slave-dealers' role in promoting trickery, rather than attributing it to the enslaved women's own designs. ${ }^{229}$

Menstruation or lack thereof in the wake of a divorce or death also seems to have been a largely individual matter in many communities, such that the woman held the discretionary power to choose when to make others in her community aware of the end of her 'idda. ${ }^{230}$ We have seen an example of this phenomenon in the case of the woman whose husband divorced her after realizing that she had not menstruated thrice after her previous divorce. All those involved besides the woman herself were unaware of how many times she had menstruated, though they suspected that there was a problem. Judith Tucker comes to a similar conclusion in her analysis of menstrual status in $17^{\text {th }}$-century Damascus. She mentions a case that came before a Hanafī judge in which a wife claimed to have menstruated three times before entering her second marriage, while her second husband accused her of lying. The judge affirmed that her oath in this matter is accepted and the marriage is valid. Tucker writes: "A woman was empowered, within the limits of the feasible, to define her own waiting period, and it was her word, not that of her husband or others, that determined when the waiting period ended. A woman who was known to have irregular menstrual periods, for example, could also testify to the completion of three menstrual cycles, and her testimony would be accepted, so long as a reasonable period of time had passed."231 The writings by Ibn Rushd about whether to believe claims about the presence of a sleeping fetus also indicate that, at least for the first few months, a woman's word was believed without any external check.

Midwives and similar experts do appear to have a role in this system, but it seems that their presence was not always thought desirable or welcome in the initial stages of a dispute. Such attitudes are particularly prominent among jurist

nary Sketch," in Slavery in the Islamic Middle East, ed. S. Marmon (Princeton, Markus Wiener Pub, 1999), 1-24.

229 Ibn Buṭlān, Risāla fī shirā al-raqīq wa-taqlīb al-'abīd, in Nawādir al-makhțūtāt edited by 'Abd al-Salām Hārūn in Nawādir al-makhțūtāt 4 (Cairo: Lajnat al-ta'līf wa'l-tarjama wa'l-nashr, 1954), 383. And al-Saqatī, Fì adāb al-ḥisba = Un manuel hispanique de Hisba (Paris: Leroux, 1931), 52.

230 The means by which such public signaling occurs seems to vary considerably. An interesting example of such signaling through the performance of a ceremonial bath can be found in a $20^{\text {th }}$-century fatwā from Timbuktu. See M. Mathee, "Women's Agency in Muslim Marriage: Fatwās from Timbuktu,” Journal for Islamic Studies 31 (2011), 91.

231 J. Tucker, In the House of the Law: Gender and Islamic Law in Ottoman Syria and Palestine (Berkeley: University of California Press, 2003), 170. 
in North Africa and Spain. There is mention of midwives being summoned to confirm the presence of genital defects and injuries to the genitals, as well as female claims of male impotence, but this was not uncontroversial. Particularly in the Mālikī school, modesty concerns complicated the assertion of sexual defects. The Mālikī school is unusual in that at least some jurists thought that proving the existence of a wife's sexual defects by means of direct examination might cause more harm than benefit to the husband. ${ }^{232}$ For example, al-Wanshārīsī quotes a question posed to the Cordovan judge Ibn Dhakwān (d. 451/1059) about a man who accuses his wife of suffering from the defect known as ratq. The judge consults with the Cordovan muftī Ibn 'Attāb (d. 462/1069) who responds that, in accordance with the legal opinion advanced by Sahnūn (d. 240/854), the woman should be examined by other women. However, he notes that his fellow Cordovan muftī Ibn al-Qațāan (d. 460/1068) rules that other women should not be examining her, on modesty grounds. ${ }^{233}$ This is consistent with Mālikī views of modesty regulations in other contexts too, which severely limit the ability of anyone apart from the spouse to legally examine a woman's vagina. (Oddly, however, Mālik is said to have called for a rather public test of male impotence, which would preserve the man's modesty but not that of his sexual partner. In this case, the man's penis is daubed with saffron and he is secluded with his partner. Then two women examine her vagina for traces of the saffron. ${ }^{234}$ )

In addition to concerns about modesty, there were other objections to the testimonies of expert women. Some jurists expressed reservations not with examination per se, but rather in regards to investing midwives with too many simultaneous roles. For example, as Ron Shaham has explored in his book on expert witnesses, Ibn Sahl (d. 486/1093), a Cordovan jurist and judge, objected to midwives being responsible for examining sold slave women, looking for defects that might annul the sale. He objected on the grounds that such a practice effectively made the midwife "a witness, a physician, and a jurisconsult (muftiyyah) at

232 al-Qarāfī, al-Dhakhīra, 4:422.

233 al-Wansharīsī, al-Mi'yār al-mu'rib, 3:132. The opposite attitude is displayed in al-Mi'yār almu'rib, 3:139. Delfina Serrano mentions that while female slaves who were victims of rape might be examined by midwives, "there is a disagreement in the case of the free woman: Ibn al-Mawwaz and Ibn Habib transmitted from Mālik that the woman, regardless of her status, must be examined by a group of women in order to determine if she has been deflowered. According to Ashhab, the free woman is not subject to this exam." D. Serrano, "Legal Practice in an Andalusī-Maghribī Source from the Twelfth Century CE: The Madhāhib al-ḥukkām fĩ nawāzil alaḥkām,” Islamic Law and Society 7 (2000), 201.

234 Al-Qayrawānī, al-Nawādir wa'l-ziyādāt, 538. 
the same time.”235 When it came to issues of paternity, there was a general reluctance to accept female testimony that could not be corroborated by a man, on the grounds that women's testimony was insufficient in most criminal cases. ${ }^{236}$ On occasion we hear of midwives testifying that a divorcée or widow is pregnant but who are then shown to be lying or mistaken. ${ }^{237}$ Here is such a case from North Africa:

Sīdī 'Abdallāh al-'Abdūsī [d. 849/1445 in the region of Fez] was asked about a woman whose husband had died, and she said she was pregnant. Some midwives knowledgeable about such matters probed her womb and said it was indeed inhabited. She remained like that for longer than the period of the 'idda, i.e. the 'idda of the widow. ${ }^{238}$ Later she wanted to marry [again] and her case was brought to the qādī al-Hașan. She said that her womb showed no indication of that which she had previously declared, and that she had menstruated twice in one month. The qāọi ordered the knowledgeable midwives to probe her womb and they said, "To us, nothing which we previously saw appears to be in her womb now." Then the qādī ordered it be testified to, and [some males] testified to what the woman and the midwives had said. She then married, consummated the marriage, and remained with her husband for about six months. Then she said, "I appear to be pregnant and it is from my deceased husband." Her husband hit her and divorced her via khul', and she remained so for about one month. Then the husband took her back, and she remained another eleven months and then gave birth. She said, "he is the offspring of my first husband." It was said to her, "did you not then marry while you were pregnant?" She said, "I feared for myself and for my money, when the Arab who asked me to marry him, because it is their custom to marry a woman to get her money." Then some of the people said to her husband: "Make her swear that the child is that of the first (husband) and leave her and her child, even if it is your son." So he made her swear and divorced her via khul' and reconciled(?) with the

235 Shaham, The Expert Witness in Islamic Courts, 96.

236 Giladi, Muslim Midwives: The Craft of Birthing in the Premodern Middle East, 113-132. In a Jewish istiftä' from eleventh-century Iraq addressed to Hayy Gaon, a husband being sued for divorce voices his disdain for midwives this way: "What does our master, the Head of the Yeshiva, say in the matter of a man who married a virgin and lived with her for about two years, and afterwards she brought him to court saying that he is impotent. She claims that she is still a virgin, while he says, 'I penetrated her and deflowered her [lit: I brought out the blood of virginity] at the time of the wedding.' She denies it and says, "Bring women who are midwives to me to check me, and they shall find that I am a virgin.' He says, 'She hates me and has set her sights on another man. I do not consider the words of midwives, and they cannot be trusted to the extent that they would make me lose, such that I would have to pay out the ketubah. For this is like witnessing, and women are unfit for witnessing." My translation of the medieval Hebrew translation of an only partially extant Judeo-Arabic original. Hebrew in Otsar ha-ge'onim ed. B. Lewin (Jerusalem: Hebrew University, 1928), 7:148. Discussion and Arabic fragment in M. Friedman, Ribui nashim be-Yisrael = Jewish Polygyny in the Middle Ages Jewish Polygyny in the Middle Ages (Jerusalem: Mossad Bialik, 1986), $169 \mathrm{ff}$.

237 Shaham, The Expert Witness in Islamic Courts, 88.

238 Four months and ten days. 
child. After this some of the people said to him, "the child is yours, notwithstanding the woman's vow." So now he seeks his son, but the relatives of the dead [first husband] are preventing him, saying "he is the son of our dead brother." Clarify for us to whom the son belongs. ${ }^{239}$

This case hints at several complicating factors which, without more detail, we cannot entirely confirm. Yet certain elements are clear: soon after becoming widowed, the widow decided that it was in her interest to be considered bound via pregnancy to her deceased husband. But then, at some later date (at least four and one-half months into her widowhood) she decided to marry again, at which point she no longer claimed to be pregnant. Six months into the second marriage, which was at least 11 months after the death of the first husband, the wife announced that she was gestating the first husband's child. This led to a

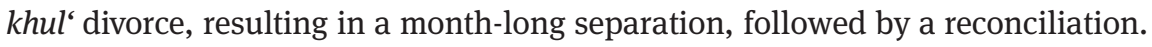
This pregnancy claim was not soon followed by the actual birth of a child. Rather, a child was finally born 11 months after the reconciliation, and thus at least 22 months (if not much later) after the death of the first husband. Throughout this saga, the midwives' testimonies confirmed the wife's own claims about the matter. And, throughout most of this timespan, the woman clearly wished to be perceived as pregnant, though it took her quite some time to actually birth a child. Her reasons for wanting to be perceived as pregnant were, ironically, to avoid the entanglements of a new marriage. Initially she dissuaded suitors by claiming to be pregnant by her deceased husband, but then decided she had best remarry. If her statement about fearing for own safety is to be believed, she remarried because she thought it would protect her from the advances of other suitors whom she perceived as being a threat. Yet she clearly had mixed feelings about her second marriage, persuading her husband to divorce her, twice, by claiming to be pregnant with another man's child. Here the impetus for claiming to be pregnant and extending her 'idda seems to be primarily that it gave her the space to be practically independent, by virtue of tying her to a dead husband rather than a living one.

This complex relationship between biological realities, legal definitions of biological phenomena, and marriage and divorce practices, meant that cultural practices influenced expectations of fertility, and that women could reframe their biological state to gain legal advantage. Sometimes legal and cultural factors created an expectation of fertility, even when biology pointed toward likely subfecundity or infertility. Such was the case when women experienced early first marriages, or when they experienced divorce somewhat early or late in life.

239 al-Wansharīsī, al-Mi'yār al-Mưrib, 4:54-5. 
When the distinctions in the legal system were difficult to apply to these nuanced biological realities experienced by subfertile and infertile women, it could be a source of confusion and frustration. On the other hand, the legal system and the community often placed a great deal of trust in women, such that they had the opportunity and flexibility to represent their reproductive status in ways that enhanced their legal position. 